\title{
CONTRADIÇÕES DA DEMOCRACIA E OPINIÃO PÚBLICA
}

\author{
Contradictions of democracy and public opinion \\ Contradicciones de la democracia y opinión pública
}

Agemir Bavaresco ${ }^{1}$

Pontifícia Universidade Católica do Rio Grande do Sul, Porto Alegre, RS, Brasil.

Francisco Jozivan Guedes de Lima2

Universidade Federal do Piauí, Teresina, PI, Brasil.

Teresa Cristina Schneider Marques ${ }^{3}$

Pontifícia Universidade Católica do Rio Grande do Sul, Porto Alegre, RS, Brasil.

\section{Resumo}

Este artigo consiste em uma análise interdisciplinar com o auxílio de teorias filosóficas, sociológicas e políticas sobre as contradições da democracia e a sua relação com a opinião pública a partir de três perspectivas: em um primeiro momento aborda os modelos normativos de democracia diagnosticados por Habermas em Inclusão do Outro, e a sua proposta de procedimento deliberativo com vistas a superar os limites dos modelos

\footnotetext{
Doutor em Filosofia pela Universidade Paris I - Pantheon-Sorbonne. Professor no Programa de Pós-Graduação em Filosofia da Pontifícia Universidade Católica do Rio Grande do Sul (PUCRS). ORCID: https://orcid.org/0000-0002-7967-4109.E-mail: abavaresco@pucrs.br

2 Doutor em Filosofia pela Pontifícia Universidade Católica do Rio Grande do Sul (PUCRS). Professor no Programa de Pós-Graduação em Filosofia da Universidade Federal do Piauí. ORCID: https://orcid.org/0000-0003-4483-8393. E-mail: jozivan2008guedes@gmail.com

3 Doutora em Ciência Política pela Universidade Federal do Rio Grande do Sul (UFRGS). Professora no Programa de Pós-Graduação em Ciências Sociais da Pontifícia Universidade Católica do Rio Grande do Sul (PUCRS). ORCID: https://orcid.org/0000-0002-6038-2704. E-mail: teresa.marques@pucrs.br
} 
liberal e republicano; depois de expor um diagnóstico basilar dos modelos democráticos, apresenta alguns pontos concernentes às contradições da democracia contemporânea a partir das análises sociológicas e da Ciência Política de Charles Tilly. Em um terceiro momento, aborda a democracia a partir do conceito hegeliano de opinião pública tendo em vista três componentes: a fenomenologia, a lógica e a política da opinião pública.

Palavras-chave: Contradição. Democracia. Opinião pública.

\begin{abstract}
This paper consists of an interdisciplinary analysis with the aid of philosophical, sociological and political theories about the contradictions of democracy and its relationship with public opinion from three perspectives: first, it approaches the normative models of democracy diagnosed by Habermas in Inclusion of the Other, and its proposal of deliberative procedure with a view to overcoming the limits liberal and republican models; after exposing a basic diagnosis of democratic models, presents some points concerning the contradictions of contemporary democracy from the sociological analyzes and political science of Charles Tilly. In a third moment, it approaches democracy from the Hegelian concept of public opinion in view of three components: phenomenology, logic and the politics of public opinion.
\end{abstract}

Keywords: Contradiction. Democracy. Public opinion.

\title{
Resumen
}

Este artículo consiste en un análisis interdisciplinario con la ayuda de teorías filosóficas, sociológicas y políticas sobre las contradicciones de la democracia y su relación con la opinión pública desde tres perspectivas: en un primer momento se aborda los modelos normativos de democracia diagnosticados por Habermas en Inclusión de Otro y su propuesta de un procedimiento deliberativo con el fin de superar los límites de los modelos liberal y republican; después de exponer un diagnóstico básico de los modelos democráticos, presenta algunos puntos con respecto a las contradicciones de la democracia contemporánea del análisis sociológico y de la ciencia política de Charles Tilly. En un tercer momento, analiza la democracia desde el concepto hegeliano de la opinión pública teniendo en cuenta tres componentes: la fenomenología, lógica y política pública.

Palabras clave: Contradicción. Democracia. Opinión pública. 
As "contradições da democracia e a opinião pública" explicitam a crise da democracia partidária concorrencial, ou seja, da "democracia representativa". Nesse modelo, a organização partidária é o principal instrumento político de acesso ao processo de tomadas de decisão nas esferas de poder. A crise da democracia representativa atinge tanto as democracias originárias, em que há uma tradição de processos eleitorais, quanto aqueles países de democratização recente, como é o caso do Brasil, com a Promulgação da Constituição Federal de 1988.

O diagnóstico da crise da democracia representativa pode ser identificada em três aspectos, segundo Claus Offe (1984): 1) desradicalização da ideologia dos partidos, adequando-se ao mercado político; 2) burocratização e centralização dos partidos, ou seja, organização política burocrático-profissional, desempenhando atividades tais como: captar recursos materiais e humanos; fazer propaganda e articular informações sobre a posição do partido a respeito de temas políticos emergentes; identificar no mercado político novos temas para formar a opinião pública a seu favor; e 3) enfim, a heterogeneidade estrutural, ideológica e cultural de seus filiados, provoca a dissolução da ideia de identidade coletiva.

Em face desse diagnóstico, que aponta as contradições da democracia, nossa pesquisa inicialmente apresenta uma proposta de releitura dos modelos normativos de democracia, pondo o modelo deliberativo enquanto alternativa aos modelos liberal e republicano. Depois, a partir de um viés das Ciência Política, descrevemos as teorias contemporâneas da democracia. Por fim, tratamos da teoria da contradição da opinião pública e seus impactos na democracia.

\section{Democracia liberal, republicana e deliberativa segundo Habermas}

\subsection{O modelo liberal de democracia}

Habermas entende que o modelo liberal de democracia é calcado no ideal de autovantagem em detrimento da cooperação e dos vínculos de solidariedade. 
Nele, o Estado é posto como uma esfera subserviente ao econômico, tendo como objetivo principal efetivar os interesses da sociedade civil burguesa, de modo que a dimensão política se dobra diante da esfera econômica. Entenda-se aqui, neste modelo, "sociedade" enquanto "sistema de circulação de pessoas em particular e do trabalho social dessas pessoas, estruturada segundo leis de mercado" (HABERMAS, 2002a, p. 270). As leis do bem comum são substituídas por leis próprias da economia, em que contam os interesses privados do homo oeconomicus. Enquanto um "aparato da administração pública", o Estado deve fazer o máximo de esforço a fim de que a economia tenha o seu êxito e funcione de acordo com a devida regularidade planejada. Ele, o Estado, é convertido em uma sociedade de mercado em que a proteção e a liberdade pessoal são prioridades, algo que segundo Hegel (2010, § 258) subverte a função essencial do Estado que consiste na busca ética do universal que, em termos políticos, é traduzível como "busca do bem comum".

Esse quadro de inferioridade do político ao econômico traz consequências para a própria dimensão jurídica, que não é acessada enquanto garantia de direitos coletivos, isto é, de todos os membros da sociedade, mas tomada enquanto "capa protetora" de indivíduos proprietários. Destarte, são colocados em risco os direitos sociais e os direitos de participação efetiva dos cidadãos na esfera pública. O poder é operado por uma determinada elite financeira e econômica que determina a agenda global, política e social. Com o capitalismo instaura-se, assim, uma nova ordem, a ordem econômica enquanto vetor central de justificação de ações e estratégias; inclusão e solidariedade perdem campo para a concorrência, desigualdade e injustiças, mormente, sociais, e o Estado torna-se uma esfera ultramínima de ação, deixando de lado o bem-estar social, e incorporado enquanto "vigia noturno" (NOZICK, 1974, p. 26) apto a proteger a propriedade privada, a implantar e garantir a ordem e a exterminar qualquer violência e ameaça ao indivíduo proprietário enquanto aquele que detém o capital. Programas sociais de transferência de renda são tidos como violações e imposições aos cidadãos-proprietários; em um Estado mínimo e neoliberal, que tem a tarefa de vigiar propriedades, as vinculações e deveres sociais são desresponsabilizados. 
O modelo liberal acentua o primado do indivíduo sobre a comunidade. Ele refuta a precedência da coletividade; o bem-estar do indivíduo é o que conta em primeiro lugar. A dimensão política não é, como em Aristóteles (1998), algo dado naturalmente, mas fruto de um contrato, é uma convenção, é artificial. $\mathrm{O}$ indivíduo é o produtor da ordem coletiva. Rompe-se, assim, com a ideia de polis, na qual o horizonte de sentido da vida ética do indivíduo só seria possível em comunidade. Pelo contrário, no modelo liberal, o sentido da vida individual já é pleno, completo, em si mesmo, recôndito no próprio eu, de modo que o "individualismo" passa a ser uma palavra-chave do seu arcabouço teórico. Este individualismo implica a esterilização das virtudes públicas, isto é, das virtudes concernentes à vida em comunidade (TOCQUEVILLE, 1987, p. 386).

Isso conduz ao que Esposito (2010) chama de "paradigma imunitário" que consiste na isenção dos deveres perante a comunidade; protegido pelo Estado em uma roupagem de direitos subjetivos fundamentais, o indivíduo fecha-se em si e rompe com a coletividade, portanto, fica imune e isento de responsabilizações e vínculos cooperativos. A isso Honneth (2015) chama de "patologia social", que significa a incapacidade de o indivíduo compreender e seguir normas sociais de cooperação. Nesse enfoque, a sociedade é útil para ele quando é estrategicamente benéfica para o êxito de suas ações individuais. Obedecendo a certa lógica concorrencial do mercado, nesse modelo, o outro é facilmente tomado como "oponente" (Gegner) em vez de parceiro (Partner) de interação (HABERMAS, 2012). A relação com o outro passa a ser meramente instrumental, no sentido que ele pode ser acessado enquanto um meio para um determinado fim, algo em sentido contrário da proposta moral de Kant da não instrumentalização de outrem com vistas à obtenção da autovantagem ou de vantagens alheias (KANT, 1974). Em um modelo liberal de democracia a política enquanto esfera de governabilidade é submetida a um realismo político, em que se efetuam jogos de interesses e disputa por poder, e a consequência disso é a tese segundo a qual os fins justificam os meios. 
Além de uma liberdade do mercado enquanto liberdade do consumo (para aqueles que o podem), o modelo liberal de democracia é embasado em um modelo "negativo" de liberdade, entendido aqui em um sentido hobbesiano enquanto "ausência de impedimentos externos para a ação" (HOBBES, 2003), ou como "não intervenção". O indivíduo pode fazer tudo que queira, contanto que não viole a liberdade dos demais. Esse tipo de liberdade funda um atomismo nas relações humanas em que cada um determina o que é ser livre, independentemente de vinculações sociais e de dinâmicas de reconhecimento mútuo. Isso tem efeito sobre a própria concepção de cidadania que assume um status de subjetividade que, em nível jurídico, estressa ao máximo o conceito de direitos subjetivos ou direitos fundamentais, mesmo que em prejuízo dos direitos sociais e políticos (HABERMAS, 2002a, p. 271). Não conta a participação social ou a participação na esfera pública, mas a autorrealização individual. A lei protege o indivíduo tanto do outro quanto do Estado. A individualidade é um espaço sagrado e intocável.

Claro que a privacidade é uma conquista moderna, mas o problema aqui em jogo é quando isso se torna um obstáculo para a construção de relações sociais e intersubjetivas autênticas. A conservatio vitae é um princípio fundamental no Estado de direito democrático, porém, o direito não pode ser reduzido a essa dimensão meramente negativa e positivista, legalista. Além dos direitos civis de liberdade, vida, igualdade perante a lei, há direitos políticos de participação na esfera pública e de sufrágio universal, e direitos sociais de bens básicos ligados à moradia, educação, saúde, emprego, subsistência, que são elementos indispensáveis para a construção robusta de um conceito democrático mais amplo de cidadania, direitos estes que não se limitam ao plano meramente individualista (MARSHALL, 1967).

\subsection{O modelo republicano de democracia}

Se o modelo liberal de democracia tem como foco a autovantagem e o fortalecimento do individualismo e da sociedade civil burguesa, o modelo republicano na visão de Habermas fortalece a polis e a comunidade 
na qual o indivíduo está inserido. O sentido da primazia do político que está na Grécia tanto em Platão quanto em Aristóteles ${ }^{4}$ é recepcionado como a razão de ser da vida ética. Democracia, nesse caso, consiste em bem comum, e o sentido da vida individual está intimamente vinculada à vida política, isto é, à participação na coisa pública (república). Conforme Jaeger (1994, p. 141), "o valor do homem e da sua conduta mede-se exclusivamente pelo bem ou pelo mal que acarretam à cidade".

O republicanismo opera em um caminho inverso do liberalismo: enquanto este acentua o individual, aquele destaca a precedência da vida comunitária (HABERMAS, 2002a, p. 270). Entre os modelos liberal e republicano de democracia, há certo paradoxo e uma tensão entre essas duas dimensões da vida ética. Não está devidamente equacionada em tais modelos a necessária fusão entre indivíduo e comunidade. Esse é um paradoxo que, de acordo com Constant (2015, p. 100), marca o conflito em termos de orientação normativa entre a filosofia política antiga e a filosofia moderna:

O perigo da liberdade antiga era que, atentos unicamente a garantir a participação no poder social, os homens não faziam muito bom uso dos direitos e gozos individuais. $\mathrm{O}$ perigo da liberdade moderna é o de que, absorvida pelo gozo de nossa independência privada e pela busca de nossos interesses particulares, renunciemos facilmente ao direito de participação no poder político (CONSTANT, 2015, p. 100).

Em termos políticos de governabilidade, uma das marcas fundamentais do modelo republicano de democracia consiste em uma indissociabilidade entre as esferas da ética e da política. A dimensão política não deve ser, assim,

\footnotetext{
4 De acordo com Dahl (2012, p. 18), Platão e Aristóteles eram críticos da democracia; Platão via na democracia um "governo de ineptos", e fazia a opção por um governo de indivíduos qualificados intelectualmente (epistemocracia), isto é, mais próximos do saber e da verdade imutável; Aristóteles, na ótica de Dahl, não gostava do poder que a expansão da democracia conferia aos mais pobres. Então, isegoria (igual participação nas assembleias e discussões na ágora) e isonomia (igualdade perante a lei), enquanto apelos democráticos, não eram princípios vistos como vantajosos para ambos os filósofos.
} 
instrumentalizada tendo em vista caprichos individuais e tendo em vista autovantagem, mas, pelo contrário, a vida individual deve se conformar à vida comunitária - daí a associação entre o republicanismo e comunitarismo. Não se trata, neste modelo, de realismo político, de conflito por poder, mas de seguimentos éticos que fortaleçam a efetivação dos bens comuns a todos os cidadãos. Em termos teóricos, o Estado, no modelo republicano de democracia, é uma comunidade política em vez de uma esfera submissa ao ordenamento econômico; sua função não consiste em garantir o êxito econômico, mas garantir o bem-estar dos cidadãos e a sua própria estabilidade.

Claro que não se pode fazer uma leitura romantizada da democracia grega, pensando que todos estavam incluídos em termos de participação, pois a história demonstrou a exclusão que havia de mulheres, estrangeiros, escravos, etc., algo que se arrastou por séculos, e ainda hoje - em pleno século XXI está presente, em países que não efetivaram um regime democrático aberto à participação de seus cidadãos nas decisões públicas. O próprio Jaeger (1994, p. 136), documenta toda a necessidade de inclusão e isonomia no contexto grego para fazer valer de fato a democracia universalmente em meio a uma aristocracia conservadora. A democracia institucionalizada é um evento tardio da modernidade europeia, em que as revoluções liberais, mesmo com suas deficiências, suplantam a velha ordem fundada nas alianças entre clero e nobreza hereditária. Esse é o parecer de Honneth quando afirma: "uma vida público-política, entendida como esfera discursiva da formação democrática da vontade de um povo que se vê soberano, tem seu surgimento factual somente nos Estados nacionais do século XIX" (HONNETH, 2015, p. 502).

$\mathrm{O}$ anti-individualismo do modelo republicano é perpassado por alguns valores inerentes: naturalização das relações sociais, subentendendo que o indivíduo é por natureza um animal político (ARISTÓTELES, 1995), integração social, reconhecimento mútuo, bem comum. $O$ atomismo liberal que entendia cada um, cada indivíduo, protegido pelo Estado e trancado em si mesmo, é ex cogitatio para o republicanismo, pois, como dito, é inadmissível que a vida política seja produto artificial de um contrato: o indivíduo já nasce 
dentro de um contexto político e comunitário e, por isso, ele não deve se isentar de compromissos para com a coletividade. Assim há uma contraposição entre o modelo de polis platônico-aristotélico e o modelo hobbesiano baseado no autointeresse. Isto é, trata-se de um modelo completamente contrário ao liberal - os valores democráticos são totalmente outros. 0 sentido de pertença à coletividade é visivelmente forte no republicanismo, a ponto de se perguntar sobre uma possível diluição da dimensão individual e da privacidade, o que põe em evidência o paradoxo supracitado entre liberdade dos antigos (comunidade) e liberdade dos modernos (indivíduo).

Juridicamente, o modelo republicano não se limita a proteger direitos subjetivos individuais; não exaure suas forças normativas em torno da autoproteção, como ocorre no modelo liberal. Além dos direitos fundamentais ligados à conservatio vitae, o modelo republicano dá relevância aos direitos de co-participação na esfera pública, aos direitos políticos e sociais de cidadania, tendo em vista o enfoque no engajamento. Se no modelo liberal de democracia, o direito é invólucro protetivo para o "eu" que legitimava a desintegração social, no modelo republicano o direito deve ser capaz de possibilitar a integração social.

Todavia, além de colocar em jogo o tema da individualidade e da privacidade, o republicanismo tem outro déficit, que segundo Habermas (2002a, p. 276), consiste na condução estritamente ética dos discursos políticos. Ele padece, no seu parecer, de um déficit, a saber, de uma idealização ética das relações, como se os indivíduos fossem adaptar seus estilos de vida e persecução de fins particulares à vida coletiva, sem possíveis conflitos. Ou seja, para Habermas, não é tão natural assim, como pressupõe o republicanismo, a articulação entre o ético e o político. É preciso, portanto, sugerir um outro modelo que tome os indivíduos de modo mais real; tal modelo é o deliberativo. 


\subsection{O modelo deliberativo de democracia}

De acordo com Mouffe (2000, p. 84), há diferentes formas de democracia deliberativa, mas ela considera duas "escolas" como sendo emblemáticas: a de Rawls, que tem, segundo ela, como seu principal seguidor Joshua Cohen; e a de Habermas, que tem Benhabib como principal discípula. Para fins de delimitação teórica, a nossa ideia aqui consiste em focar na contribuição habermasiana mediante a sua propositura de um modelo procedimental de deliberação democrática.

A tese precípua de Habermas (1997, p. 18) é que "o processo da política deliberativa constitui o âmago do processo democrático". Ele considera que os modelos liberal e republicano de democracia são limitados; o liberal porque é excessivamente individualista ao centrar-se na autovantagem, o republicano porque é excessivamente idealista ao pressupor uma articulação indissociável entre o ético e o político (HABERMAS, 2002a). Além disso, o modelo liberal transforma o Estado em um instrumento para o êxito dos processos econômicos, e o modelo republicano fortalece em excesso a comunidade política correndo-se o risco de obliteração do indivíduo. Como uma forma de sanar tais déficits de intersubjetividade, Habermas propõe o modelo deliberativo de democracia a partir de um quadro de sua teoria do agir comunicativo. De acordo com Gutmann e Thompson (2004, p. 3), a democracia deliberativa afirma a necessidade de justificação de decisões por parte dos cidadãos e de seus representantes. As decisões não podem ser realizadas a partir do arbítrio ou do poder de um soberano, mas a partir de razões convincentes para os envolvidos na decisão. Outro ponto, é que na deliberação, o processo democrático não pode ser esgotado por jogos políticos de ajustes e barganhas entre parlamentares, isto é, não pode ser objeto de lobby, de formas de influenciação da arena política pelo poder econômico, tal qual como é viável no modelo liberal economicista. Deliberação, nesse sentido, vai além de meras "sondagens demoscópicas" e de dinâmicas eleitorais midiaticamente manipuladas (HABERMAS, 2014, p. 98). Como bem destaca Audard, "enquanto as democracias represen- 
tativas parlamentares clássicas veem no voto e na negociação entre os interesses particulares o processo político por excelência, a democracia deliberativa atribui a preponderância à deliberação pública, bem como ao engajamento dos cidadãos" (AUDARD, 2006, p. 64).

A participação nas decisões acerca dos rumos da vida coletiva, dentro de um modelo deliberativo de democracia, não deve ser uma prerrogativa de um determinado grupo de poder, seja ele de capital financeiro ou de capital intelectual, ou de qualquer outro tipo de poder, mas deve ser um direito de todos os cidadãos. Trata-se de um modelo inclusivo de democracia. Conforme frisam Cohen e Arato (1992, p. 214), Habermas, na sua reconstrução do conceito de esfera pública e de seus desdobramentos históricos e sociológicos, opõe-se a um tipo de esfera pública restrita aos letrados e salões, tal qual se desenvolveu na Europa do século XVIII e XIX.

Para ser mais exato, Habermas não apenas se opõe, mas rechaça a possibilidade de uma esfera pública burguesa que, no seu entender, não é esfera pública. Para ele, esfera pública é um conceito radicalmente democrático, e se faz com participação e inclusão: "a esfera pública burguesa se rege e cai com o princípio do acesso a todos. Uma esfera pública, da qual certos grupos fossem eo ipso excluídos, não é apenas, digamos incompleta: muito mais além, ela nem sequer é uma esfera pública" (HABERMAS, 2003, p. 105). Óbvio que a universalização da participação nas decisões públicas, requer, dentro de um Estado de direito presumivelmente democrático, a formação e o esclarecimento dos cidadãos acerca de seus direitos e deveres, algo, por exemplo, reivindicado por Kant em seu século XVIII quando denunciava os investimentos bélicos por parte do Estado prussiano, em vez de investir na formação para a cidadania (KANT, 1993).

O modelo deliberativo de democracia, segundo Habermas (2002a), como dito acima, rechaça os déficits dos modelos liberal e republicano, porém mantém algumas bases imprescindíveis, a saber: do modelo liberal, preserva a defesa dos direitos subjetivos e fundamentais, que, enquanto uma conquista moderna, deve ser inalienável, pois, do contrário, recair-se-ia em um Estado totalitário que aniquilaria os direitos dos indivíduos; do modelo republicano, 
recepciona valores fundamentais para o ethos democrático ${ }^{5}$, como a cooperação, a solidariedade, e responsabilização perante a comunidade cívica.

Na perspectiva liberal, o processo democrático se realiza exclusivamente na forma de compromissos de interesses. Eas regras da formação do compromisso, que devem assegurar a equidade dos resultados, e que passam pelo direito igual e geral ao voto, pela composição representativa das corporações parlamentares, pelo modo de decisão, pela ordem dos negócios, etc., são fundamentadas, em última instância, nos direitos fundamentais liberais. Ao passo que a interpretação republicana vêa formação da vontade democrática realizando-se na forma de um autoentendimento ético-político, em que o conteúdo da deliberação deve ter o respaldo de um consenso entre os sujeitos privados, e ser exercido pelas vias culturais; [...]. Ora, a teoria do discurso assimila elementos de ambos os lados, integrando-os no conceito de um procedimento ideal para a deliberação e a tomada de decisão. Esse procedimento democrático estabelece um nexo interno entre considerações pragmáticas, compromissos, discursos de autoentendimento e discursos da justiça, fundamentando a suposição de que é possível chegar a resultados racionais equitativos (HABERMAS, 1997, p. 19).

De acordo com Petrucciani (2014, p. 191), Habermas estabelece sua proposta de democracia deliberativa a partir de uma relação de complementaridade e cooriginariedade entre autonomia privada de liberdade individual (matriz liberal) e soberania popular/autonomia pública dos cidadãos (matriz republicana). Vale ainda ressaltar que o modelo deliberativo de democracia não é um modelo substancialista, isto é, um tipo de metafísica

\footnotetext{
5 Forst (2010, p. 115), define ethos democrático nos seguintes termos: "modo como cidadãos se entendem como membros de uma comunidade política, quais as coisas que têm em comum e quais suas responsabilidades. Em particular, estão em questão as condições de possibilidade e o modo de uma 'justificação pública' de normas legítimas em discursos democráticos".
} 
que fornece conteúdos e/ou princípios dados e prontos, mas é um modelo procedimental de democracia, portanto, ele fornece regras, procedimentos, mediantes os quais os cidadãos devem chegar a acordos sobre a vida em coletividade. Tal qual o imperativo categórico de Kant, ao menos na sua forma, ele não diz o que fazer, mas como fazer: "a teoria do discurso não torna a efetivação de uma política deliberativa dependente de um conjunto de cidadãos coletivamente capazes de agir, mas sim da institucionalização dos procedimentos que lhes digam respeito" (HABERMAS, 2002a, p. 280).

O modelo de democracia deliberativa em Habermas, segundo White (1995, p. 73), não é um modelo substantivo em que se diz o que fazer, mas é um modelo procedimental, no qual são postas as regras básicas das decisões concernentes à esfera pública; portanto, ele não oferece conteúdos de ação, mas normas e orientações, procedimentos, através dos quais os agentes podem discutir valores fundamentais orientados para o consenso, mesmo que mínimo, acerca do publicum, isto é, daquilo que lhes interessa para a vida coletiva. Nesse sentido, Habermas segue o procedimentalismo de Kant, e também o de Rawls, entretanto, diferindo deles no seguinte aspecto: não é operado a partir de uma subjetividade mentalista como em Kant, e não depende de uma posição original afastado dos contextos sociais como em Rawls. É um procedimento feito para cidadãos concretos que participam da arena deliberativa.

A tese de Habermas é que a deliberação, dentro de um enquadramento de teoria do agir comunicativo, deve seguir algumas regras basilares, tais como:

(a) Publicidade e inclusão: ninguém que, à vista de uma exigência de validez controversa, possa trazer uma contribuição relevante, deve ser excluído; (b) direitos comunicativos iguais: a todos são dadas as mesmas chances de se expressar sobre as coisas; (c) exclusão de enganos e ilusões: os participantes devem pretender o que dizem; e (d) não-coação: a comunicação deve estar livre de restrições que impedem que o melhor argumento venha à tona e determine a saída da discussão (HABERMAS, 2002, p. 67). 
Essas regras aparecem bem formuladas em termos de Ciência Política em Dahl (1990, p. 52-53) - inclusive o próprio Habermas o cita - quando apresenta cinco critérios para um processo democrático presumivelmente exitoso, a saber:

1 - Votos iguais: os votos devem ser alocados igualmente entre os cidadãos; 2 - participação efetiva: durante todo o processo de tomada de decisões coletivas de cumprimento obrigatório, todo cidadão deve ter oportunidade adequada e igual de manifestar a preferência pelo resultado final; 3 entendimento esclarecido: cada cidadão deve ter adequadas e iguais oportunidades, de descobrir e justificar sua preferência no assunto a ser decidido; 4 - controle final da agenda do demos: o demos precisa dispor de oportunidade exclusiva de tomar decisões que determinem que assuntos devem ou não ser decididos por processos que satisfaçam os três primeiros critérios; 5 - inclusão: o demos deve incluir todos os membros adultos, exceto pessoas em trânsito ou que se prove que são mentalmente deficientes (DAHL, 1990, p. 52-53).

Dahl põe critérios e procedimentos do processo de participação democrática, porém alerta que a igualdade política pode ser minada por meio de desigualdades de fato, isto é, desigualdades econômicas e sociais, mediante o fortalecimento do capitalismo e da burocracia (DAHL, 1990, p. 55). Isso é diagnosticado por Habermas (2012) como "colonização" do mundo da vida através do poder e do dinheiro, enquanto meios capazes de minar as possibilidades de integração social e de participação ativa na esfera pública.

Cabe, enfim, frisar que a deliberação não é um mecanismo quantitativo, em que uma maioria se impõe sobre uma minoria; não é um processo de massificação, mas um procedimento qualitativo, em que a justificação e os argumentos devem ser a chave da escolha de princípios orientadores da esfera pública. Nesse jogo de dar e pedir razões, há espaço não apenas para o consenso, mas também para o dissenso; conforme Pettit (2003, 
p. 371), "determinadas decisões e determinadas políticas podem atrair apoio majoritário, ao mesmo tempo em que representam a mais arbitrária interferência nas vidas das minorias." Sua ideia é que o fortalecimento da democracia se dá pela via da contestabilidade; contestar é um direito cabível no uso público da razão por parte de cidadãos democráticos e abertos ao pluralismo ${ }^{6}$, e quando se contesta, comumente emerge a opinião pública contramajoritária. Nesse sentido, justificação e argumentação de decisões públicas, capacidade de consenso e, sobretudo, contestação, são valores que dão vitalidade à democracia pensada enquanto processo deliberativo.

Todavia, a institucionalização de novas áreas dos saberes dedicados ao estudo da democracia tais como a Ciência Política, fortaleceram novas perspectivas e concepções do regime político. Com o objetivo de compreendê-las, passamos à análise das contribuições da Ciência Política para a compreensão das contradições das teorias democráticas.

\section{A Ciência Política, as teorias contemporâneas da democracia e suas contradições}

Se a filosofia tem um importante papel para a origem e aprofundamento do pensamento democrático, cabe destacar que, no século $X X$, com as transformações políticas que marcaram o período e a institucionalização da Ciência Política enquanto disciplina, o debate se tornou mais diverso e sobretudo mais processual.

Para grande parte dos estudiosos da democracia que receberam destaque na Ciência Política, o pensamento democrático tem origem em filósofos gregos da Antiguidade como Aristóteles, que se preocupou em

\footnotetext{
6 De acordo com Rancière (2014, p. 17), a democracia atual é perpassada por um paradoxo: de um lado, ela é o reino do excesso, o reino da pluralidade e das paixões; de outro, Ihe exigem que tais paixões da vida coletiva e a pluralidade sejam reprimidas - essa é a demanda de conservadores e totalitários. Em um modelo democrático-deliberativo, as diferenças e os pluralismos, desde que sejam "razoáveis" (respeitem direitos humanos, respeitem princípios de justiça, respeitem-se mutuamente, cumpram termos equitativos de cooperação etc.), para usar uma expressão rawlsiana, são bem-vindas (Cf. RAWLS, 2011, conf. II, § 1).
} 
classificar as formas de associação política. Os textos de filósofos da era moderna tais como Jean-Jacques Rousseau, também são considerados importantes contribuições para a construção de um pensamento democrático. Cabe destacar que os últimos ajudaram a fortalecer leituras da democracia com caráter normativo. Algumas dessas leituras inclusive inspiraram os levantes revolucionários do século XVIII, que marcaram, segundo Samuel Huntington, o início da primeira onda democrática (Huntington, 1994, p.23). Tal onda, segundo Huntington, além de breve - uma vez que logo foi seguida por uma onda reversa -, também é marcada pelo fato de que os critérios que definiam os regimes enquanto tal seriam bastante limitados se analisados à luz das teorias contemporâneas da democracia7 (Huntington, 1994, p. 26). Além disso, cabe destacar o alcance limitado dessa onda, uma vez que, ainda que as revoluções americana (1763-1776) e francesa (1789-1799) tenham tido um importante valor simbólico para todo o mundo ocidental, elas não foram capazes de abalar a legitimidade dos regimes de outras naturezas, tais como os monárquicos com o poder altamente centralizado na figura do monarca. Justamente por isso, o período que se inicia com a primeira onda e vai até a segunda onda - que se inicia com o fim da segunda guerra mundial - foi um período no qual prevaleceram os estudos de pensadores que entendiam a democracia como "fonte" ou propósito. Tratava-se de argumentar e defender a ideia de que a democracia seria "desejável" ou uma forma de regime ideal (SANTOS; AVRITZER, 2009, p. 39-40). Isto é, prevaleceram as leituras normativas do regime político.

A segunda onda, por sua vez, causou um novo efeito, que foi a concretização da democracia enquanto um "valor". Com a vitória dos Aliados na Segunda Guerra Mundial e a chamada segunda onda de democratização, os Estados Unidos, que então emergiram como nova potência mundial, se empenharam

\footnotetext{
7 Os dois pré-requisitos são os seguintes: 1) que $50 \%$ dos homens adultos tenham direito a voto; e 2) que o executivo conte com apoio majoritário de um parlamento eleito por meio de eleições periódicas (HUNTINGTON,1994, p. 26).
} 
em defender o regime democrático enquanto um antídoto para regimes totalitários como aqueles que marcaram o conflito. Em termos geográficos, essa onda teve um maior alcance. Contudo, foi ainda mais curta em termos cronológicos, se comparada com a onda anterior, uma vez foi brevemente atingida por uma onda reversa de regimes autoritários (HUNTINGTON, 1994). A partir da década de 1960 regimes autoritários se instalaram na América do Sul, na Ásia e na África. Contudo, de forma paradoxal, em um contexto marcado pela Guerra Fria, membros da elite política que estavam à frente desses regimes muitas vezes argumentavam que o regime autoritário se fazia necessário para defender a democracia. O caso mais exemplar disso é o próprio caso brasileiro, que se esforçou em manter uma aparência democrática, ao manter o congresso e um sistema bipartidário, apesar de todas as limitações impostas aos direitos civis e às liberdades democráticas. Isso comprova o argumento de Giovanni Sartori que entende que no século XX a democracia se tornou um significado de "civilização", fazendo com que todos queiram reivindicá-la enquanto uma característica de si mesmos, mesmo quando não são governos democráticos (SARTORI, 1987, p. 3-4).

Essa importante transformação também afetou sobremaneira o pensamento democrático. As ondas democráticas, as suas ondas reversas e as disputas simbólicas em torno do significado da democracia inspiraram investigadores a refletir sobre a sua definição, a ocorrência de regimes democráticos e suas derrocadas. No período, predominou a perspectiva de que era necessário se distanciar das leituras normativas da democracia e compreender como os regimes democráticos de fato funcionavam. Como eles surgem? Porque eles caem? Quais variáveis explicam tais processos? $\mathrm{O}$ que afinal define uma democracia? Essas perguntas incentivaram investigadores, que, preocupados em oferecer respostas empíricas para estas questões, se distanciaram da Filosofia, da História e de outras disciplinas 
para construir ferramentas metodológicas próprias, contribuindo assim para a construção de uma nova disciplina , a Ciência Política (DUVERGER, 1976).

Entre tais ferramentas, destaca-se a análise comparada, a quem inclusive se deve o surgimento da Ciência Política para Bertrand Badie e Guy Hermet (BADIE; HERMET, 1993, p. 15). A metodologia comparada foi fundamental para a compreensão de processos de transição política, uma vez que os estudos comparados contribuíram para a construção de conceitos tais como democracia, liberalização e democratização a partir de uma análise baseada na verificação de processos empíricos (MARQUES, 2010, p. 67). Para Leonardo Avritzer e Sérgio Costa, tais estudos comparados de processos de transição política consolidaram a Ciência Política, disciplina que se institucionalizou na América Latina apenas na década de 1970 (AVRITZER; COSTA, 2004, p. 703). Além disso, eles ajudaram a construir as chamadas teorias contemporâneas da democracia. Tais estudos ficaram marcados pela sua ênfase na análise empírica de processos de longa e média duração e pelo recurso ao método comparado.

Tais teorias assumiram diferentes perspectivas da democracia. Existem diferentes classificações das teorias contemporâneas da democracia na Ciência Política. Dentre tais classificações, podemos elegemos aquela elaborada por Charles Tilly, uma vez que se trata de uma das revisões teóricas críticas mais recentes e em uso crescente pelos cientistas políticos. A partir dessa classificação, espera-se apreender aspectos gerais das teorias consideradas mais importantes para essa disciplina.

Tilly entende que as definições da democracia podem ser resumidas em quatro tipos, quais sejam: constitucional, substantiva, processo-orientadas e processual (TILLY, 2007, p. 7-9). A primeira se resumiria à análise de sistemas legais que dizem respeito ao ativismo e à participação política. O segundo tipo foca em condições de vida e entende a política

\footnotetext{
8 Outros fatores além da construção de ferramentas metodológicas próprias ajudam a constituir uma disciplina, tais como a institucionalização e construção de uma identidade profissional, entre outros. Como não é o objetivo do artigo debater essa questão, recomendamos ver as seguintes contribuições sobre História da Ciência Política: FARR, 1988; ARTAZA, 2015.
} 
enquanto uma ferramenta para aprimorá-la, com ênfase na perspectiva dos cidadãos para avaliar os regimes políticos. Por sua vez, a perspectiva processual-orientada parte de uma lista de processos que devem ser constantemente incrementados pelo governo para que o país seja considerado democrático. Robert Dahl, autor de A poliarquia (1997) definiu cinco critérios para a classificação de regimes democráticos que, segundo Tilly, servem como base para a maioria das obras teóricas que partem dessa perspectiva. São eles: efetiva participação, caráter igualitário do voto, oportunidades iguais de compreensão das opções políticas e das suas consequências; controle de agenda e inclusão de adultos (TILLY, 2007, p. 7-9). Por fim, a perspectiva processual determina uma lista mínima e fixa de práticas governamentais que devem ser cumpridas pelo governo para que o regime político seja considerado democrático. Tais práticas são centradas na competição entre membros da elite pelos cargos de cúpula:

De acordo com o critério por nós adotado, democracia não significa e nem pode significar que o povo realmente governe em nenhum dos sentidos óbvios dos termos "povo" e "governar". Democracia significa tão somente que o povo tem a oportunidade de aceitar o rejeitar os homens que hão de governá-la. Mas como o povo também pode decidir isso por termos absolutamente não democráticos, tivemos de restringir a nossa definição acrescentando outro critério identificador do método democrático, a saber, a competição livre entre os aspirantes à liderança política pelo voto do eleitorado (SCHUMPETER, 2017, p. 387).

Assim, pode-se afirmar que essa abordagem teórica - também chamada de perspectiva "mínima" da democracia - se concentra na concepção da democracia enquanto um conjunto de regras de competição pelos cargos de cúpula do governo, ou, como colocado por Tilly, no cumprimento de uma lista mínima de pré-requisitos. Entre os principais autores dessa pers- 
pectiva, destaca-se Joseph Schumpeter, autor de Capitalismo, socialismo e democracia (1943) cujo modelo de democracia a define enquanto um método de seleção de elites (SCHUMPETER, 2017). Entre os pontos que devem fazer parte do método, pode-se destacar, 1) a existência de um sistema político multipartidário; 2) sufrágio universal; 3) eleições competitivas, livres, justas e regulares; e 4) acesso público aos principais partidos políticos por meio das mídias e campanhas eleitorais (TILLY, 2007, p. 8).

Existem diferentes leituras dessa perspectiva. Para Guilhermo O'Donnell, o fato de ser elitista não necessariamente impõe o caráter minimalista à proposta teórica de Schumpeter. Para O'Donnell, ao definir condições externas ao processo eleitoral para a efetivação dos pontos que fazem parte do método, tais como liberdades básicas, princípios legais e morais, entre outros, Schumpeter propõe uma perspectiva mais ampla de democracia (O'DONNELL, 2011, p. 24). Trata-se de um modelo considerado liberal democrata por MACPHERSON (1966 apud SANTOS; AVRITZER, 2009) e classificado como mínimo e elitista por Carole PATEMAN (1992), por exemplo. Ainda que essa definição de democracia possa ser considerada limitada, pode-se afirmar que na segunda metade do século XX a perspectiva processual se tornou hegemônica na ciência política. Tal perspectiva tem origem nos debates sobre a relação entre democracia e capitalismo, a centralidade da burocracia estatal e a valorização da representatividade enquanto solução para os problemas coletivos de sociedades políticas complexas (SANTOS; AVRITZER, 2009, p. 43-48).

O debate em torno da validade da teoria hegemônica da democracia marcou a segunda metade do século XX na ciência política e aos poucos ganharam forças as perspectivas que apontavam os limites e as contradições da perspectiva mínima de democracia. De acordo com Pateman, a perspectiva minimalista se opõe frontalmente com as contribuições filosóficas para o pensamento democrático. Segundo a autora: 
O ponto de partida da análise de Schumpeter é um ataque à noção de teoria democrática enquanto uma teoria de meios e fins; democracia, afirma ele, é uma teoria dissociada de quaisquer ideais ou fins. 'Democracia é um método político, ou seja, trata-se de determinado tipo de arranjo institucional para se chegar a decisões políticas - legislativas e administrativas'. Na medida em que afirma uma "lealdade sem compromissos" à democracia, supunha-se que o método cumprisse outros ideais, por exemplo, o de justiça (...) De acordo com essa definição, a competição pela liderança é a característica distintiva da democracia (PATEMAN, 1992, p. 12-13).

Assim, para muitos intérpretes de Schumpeter, a perspectiva minimalista, ao reduzir a democracia a um método, retira da análise dos regimes outras dimensões além da institucional. De acordo com essa leitura crítica, tal perspectiva desvaloriza as leituras mais amplas de democracia e se afastou das leituras clássicas de democracia que deram início ao debate democrático, dentre as quais, aquelas propostas por filósofos políticos que incluíam a participação dos cidadãos e o processo de formação de opinião pública na análise de regimes políticos (PATEMAN, 1992, p. 28). Ao contrário, na perspectiva que se mostrou hegemônica na Ciência Política durante décadas, a apatia política e a participação limitada pela representação política, passaram a ser consideradas positivas para a estabilidade do regime.

Cabe destacar que a opinião pública, bem como o processo de formação de opinião pública também são desvalorizados por essa perspectiva, mas não descartados. Para Pateman, autores como Bentham e James Mill se assemelham à perspectiva schumpeteriana e valorizavam o processo educativo voltado para a escolha de bons líderes, uma vez que "nenhum dos autores tinha a expectativa de que as opiniões se formassem no vácuo" (PATEMAN, 1992, p. 31). Todavia, fica claro que o foco não é o processo educativo em si, e sim, o resultado final das urnas: "a preocupação principal deles era mais com a escolha de bons representantes (líderes), do que com a formulação das opiniões do eleitorado" (PATEMAN, 1992, p. 31). 
Contudo, no Brasil, com a terceira onda de democratização e os processos participativos que começam a ganhar visibilidade ao longo da década de 1990, a teoria hegemônica passou também a ser confrontada com perspectivas sociológicas ou participativas da democratização. Assim, perspectivas que abordam a cultura política - com foco em condições de vida, segundo Tilly -, bem como as perspectivas processo-orientadas, passaram a ter maior aderência na Ciência Política brasileira, que foi fortemente orientada pela perspectiva minimalista. Segundo Avritzer e Costa, as abordagens sociológicas passaram a inserir dimensões culturais e sociais na análise de regimes e passaram a ganhar força ao argumentarem que a democratização é um processo nunca de fato findo (AVRITZER; COSTA, 2004, p. 704).

Avritzer e Costa consideram que uma contribuição importante para esse debate é o aprofundamento do conceito de espaço público e opinião pública, compreendendo o papel desse debate para o enfrentamento das contradições da democracia. Para tanto, os autores propõem um debate com filósofos como Habermas para dar ênfase ao potencial de crítica dos cidadãos e sua contribuição para o regime democrático, bem como da importância do processo educativo em si para o regime. Dessa forma, a opinião pública e sobretudo, o seu processo de construção, passam a ser considerado importantes para a análise e definição de regimes políticos:

A fonte da legitimidade política não pode ser, conforme Habermas, a vontade dos cidadãos individuais, mas o resultado do processo comunicativo de formação da opinião e da vontade coletiva. É esse o processo que, operado dentro da esfera pública, estabelece a mediação entre o mundo da vida e o sistema político, permitindo que os impulsos provindos do mundo da vida cheguem até as instâncias de tomada de decisão instituídas pela ordem democrática (AVRITZER; COSTA, 2004, p. 708-709). 
Assim, diferente do proposto pela teoria mínima da democracia, a proposta sociológica valoriza o processo de formação de opinião pública. A opinião pública seria a fonte de legitimidade do regime e não apenas os resultados das urnas. A crise política recente, iniciada em 2014, fortaleceu ainda outras abordagens que apontam o papel dos protestos no processo político recente brasileiro, tais como a própria abordagem processual, tal como proposta por Tilly.

Ao evidenciar os limites das abordagens tradicionais para apreender os processos em curso, a crise da democracia brasileira nos convida a um reexame da própria lógica da explicação na ciência política. Nossa incapacidade de compreender e antecipar a mudança social parece estar de certa forma relacionada à dificuldade que temos tido de explicar processos. Precisamos discutir o que temos explicado na ciência política brasileira, como temos explicado, e o que temos deixado ao largo (TATAGIBA, 2017, p. 74).

Dessa forma, parece pertinente refletir sobre e trabalhar em torno da possibilidade de aproximação da ciência política com a filosofia ao voltar a incluir o tema da opinião pública no debate. Para tanto, faz-se necessário refletir acerca das contradições que fazem parte dessa relação entre democracia e opinião pública.

\section{Opinião pública, contradição e democracia}

O tema da democracia e da opinião pública permite colocar vários problemas: Como definir/redefinir e/ou formar/transformar a esfera pública em uma esfera mais democrática? Qual é o papel das mídias na realização da democracia mediatizada pelo poder do discurso e/ou dos discursos da liberdade de imprensa e do pluralismo institucionalizado? Ou seja, quais são as condições para um projeto democrático viável através das práticas e teorias 
da democracia, como liberdade de informação/cidadania, responsabilidade democrática, poder político e ideologia, democracia local e global, guerras, invasões e políticas internacionais, sobretudo na perspectiva comparada entre países democráticos, não democráticos e em vias de democratização?

Essas questões e desafios encontram muitas respostas em exemplos de modos de formar e transformar a esfera pública e sobre o papel das mídias na democratização do poder político, da ideologia e dos mecanismos de representação e participação na esfera pública. Há experiências micro e macro da relação entre mídias, democracia e opinião pública, com destaque para o papel das mídias nas eleições e nos processos judiciais em vários países.

Considerando os problemas acima levantados, propomos um conceito básico de opinião pública que servirá como hipótese de pesquisa. Hegel na Filosofia do Direito afirma o seguinte:

A liberdade subjetiva, formal, de que os [indivíduos] singulares como tais tenham e externem seu julgar, opinar e aconselhar próprios sobre os assuntos universais tem seu fenômeno no conjunto que se chama opinião pública. O universal em si e para si, o substancial e o verdadeiro, está nisso ligado a seu contrário, ao próprio e particular do opinar para si dos muitos; por isso essa existência é a contradição presente de si mesma, o conhecer enquanto fenômeno; a essencialidade tão imediata como a inessencialidade (HEGEL, 2010, § 316).

Este parágrafo explicita o que é a opinião pública para Hegel. Trata-se de um silogismo composto de três momentos: a) Singularidade: $O$ fenômeno da opinião pública engloba o conjunto dos indivíduos que tem a liberdade subjetiva de externar seu julgar, opinar e aconselhar a partir de sua singularidade a respeito de assuntos universais; b) Universalidade: $O$ universal é a verdade, porém, ela aparece misturada com a; e c) Particularidade que opina sobre muitas coisas. A universalidade enquanto verdade está unida ao seu oposto, isto é, à falsidade. Então, o silogismo da opinião pública, 
com essa figura S-U-P explicita o ser aí da subjetividade do conceito. O significado objetivo deste silogismo é que o universal se constitui no meio termo dos extremos, ou seja, da singularidade e da particularidade. $\mathrm{O}$ silogismo do ser aí é chamado de qualitativo, pois, ele atribui apenas uma qualidade sobre um fenômeno. Por isso, ele não consegue realizar o seu significado objetivo, uma vez que se restringe a opinar sobre uma qualidade externa e contingente. Ou seja, o silogismo do ser aí ou qualitativo carece de objetividade, porque lhe falta o significado objetivo uma vez que fica restrito a um opinar ainda subjetivo formal, sem conteúdo concreto. Então, o silogismo S-U-P entra em contradição consigo mesmo e exige uma nova figura silogística que é o silogismo da reflexão. Isto significa que o silogismo do ser aí da opinião é a contradição entre o formal e o concreto, o subjetivo e o objetivo, o essencial e o inessencial. Ao falar do par essencial e inessencial, Hegel introduz o começo da lógica da essência, ou seja, a lógica da reflexão. Aqui, o silogismo da reflexão implica em uma dialética reflexiva dos termos do silogismo. As relações de reflexão implicam uma mediação dos termos que na esfera do ser aí eram ainda externas e imediatas. Agora, temos uma relação mais concreta e objetiva. Por isso, o conceito esboçado acima implica a articulação dos dois silogismos: do ser aí e da reflexão (ORSINI, 2016, p. 26, 53). Então, a opinião pública (daqui para frente OP) é um silogismo do ser aí, pois, o indivíduo afirma as suas opiniões na imediatidade singular de seu opinar, julgando a realidade segundo o universal e o verdadeiro, porém, filtrado segundo os seus interesses particulares. Há neste silogismo uma falta de objetividade, por isso, dá-se a contradição entre o essencial e o inessencial, ou seja, a mediação reflexiva que conduz ao silogizar da opinião. Portanto, nosso conceito de OP articula dois silogismos: o ser aí e a reflexão que explicitam a contradição do ato de opinar. A partir deste conceito, apresentamos a fenomenologia da opinião, isto é, a luta das autoconsciências pelo reconhecimento da sua opinião, depois, a lógica da contradição como elemento constitutivo da OP e, por último a política enquanto mediação organizacional da OP. 


\subsection{Fenomenologia da Opinião Pública}

O conceito de esfera pública constitui-se, historicamente, ao mesmo tempo em que se institui o conceito de opinião pública. Ambos têm como base o conceito de publicidade. Kant afirma que a razão pública é o conceito que expressa o ingresso da Modernidade na maioridade, ou seja, trata-se de uma razão que rompe com o princípio do segredo das monarquias despóticas. As mídias nacionais são um meio importante para a constituição da esfera pública e a consolidação do conceito de publicidade. Porém, um novo cenário desenha-se com o fenômeno da globalização que implica na elaboração de um novo conceito de publicidade internacional, o qual nos permite colocar as seguintes questões: articula-se, com isso, uma opinião pública internacionalizada? Qual é o seu público alvo? Quais são as suas diferentes expressões? Em que medida os governos nacionais são condicionados por ela, na condução de seus programas e de suas decisões políticas? Qual é o grau de influência da opinião pública internacional sobre as agendas e as políticas internacionais? Sob o ponto de vista teórico, o conceito de esfera pública tal como foi elaborado por Habermas, em Mudança estrutural da esfera pública (1984), em um quadro de referência nacional, precisa ser validada e atualizada em um cenário de fóruns e eventos estatais e alternativos internacionalizados?

Os públicos em nível nacional e regional informam-se, debatem e propõem diferentes opiniões e decisões sobre temas mundiais, a partir de fóruns e organizações alternativos, tornando explícita uma contradição na opinião pública cada vez mais complexa e plural. A informação e a formação da opinião pública internacional são produzidas, em grande parte, pelas mídias privadas e públicas e pelo que alguns denominam de empresários da opinião e as redes sociais. Os grandes temas e agendas internacionais não surgem por acaso, mas são formatados e determinados a partir de interesses de grupose de atores privados e públicos. Ora, a opinião pública é um fato contraditório, pois expressa os diferentes interesses dos grupos e das organizações culturais, econômicas e políticas regionais e a pressão sobre os governos nacionais. 
Enfim, constata-se a instituição de uma nova esfera pública internacional, veiculada pelas mídias e influenciada pela opinião pública. Resta saber se esta esfera pública internacional valida e estimula a expansão das democracias locais ou nacionais; se ela contribui na solução da crise ecológica e na garantia da sustentabilidade da ecosfera e da biosfera; se ela favorece na constituição de mais justiça nas relações humanas, etc.

Há uma luta das autoconsciências pelo reconhecimento da sua opinião que tem na clássica figura do senhor-servo da Fenomenologia do Espírito de Hegel, os momentos do desdobramento de autoafirmação das pessoas e organizações que reivindicam o reconhecimento de suas vontades, desejos e interesses expressos nas opiniões. Essa figura da luta das autoconsciências é assimétrica pois, o senhor quer impor a sua opinião, enquanto o servo resiste defendendo outra opinião. A luta alcança um ponto de tensão máxima que precisa da explicitação das contradições através das mediações da esfera pública. Porém, para alcançar esse nível de mediação há uma dialética da experiência da consciência de opinar em três momentos: a consciência sensível, a consciência perceptiva e a consciência em contradição.

a) Opinião singular - Hegel afirma acima na Filosofia do Direito, § 316: "Por isso essa existência é a contradição presente de si mesma, o conhecer enquanto fenômeno", isto é, o processo do conhecimento do opinar é um fenômeno que se dá como contradição da opinião de muitos. Hegel em sua Fenomenologia descreve a função da contradição na experiência de alcançar a verdade que se dá através das figuras da certeza sensível, da percepção e do entendimento dualista (GABOARDI, 2008).

A opinião singular expressa uma singularidade: "Este partido de direita". Porém, ela se depara com outros partidos: "Este partido de esquerda”; “Este partido de extrema direita" etc. Então, a consciência da opinião singular defronta-se com muitas opiniões singulares, uma diferente da outra e opostas a outras. Então, a opinião singular não é a base da verdade, pois, nós temos uma fragmentação de opiniões que sempre podem ser ditas. Porém, a experiência da consciência ao fazer aquelas afirmações afirma a verdade que está na representação política de um 'partido', isto é, na 
universalidade de um partido político. Então, a verdade da experiência está no conjunto dos singulares dos partidos que estão embasados na universalidade da representação do partido. Nesse momento a consciência passa da opinião singular para a experiência da opinião perceptiva.

b) Opinião perceptiva - Agora a opinião perceptiva é capaz de perceber o conjunto dos singulares em um universal. A opinião perceptiva afirma: "Estes partidos representam os diferentes interesses singulares do povo". Ou seja, o partido é a universalidade que inclui os diferentes interesses. Os diferentes partidos têm interesses opostos. Por isso, os partidos são um pluralismo de interesses entre si opostos, ou seja, os partidos são, ao mesmo tempo, unos e múltiplos. O conhecimento da opinião percebe esta contradição imediata de uma realidade em que há muitos interesses particulares representados por universalidades em oposição, os quais são os partidos. Esse é o novo momento da experiência da consciência da opinião: o entendimento ou a consciência dualista.

c) Opinião em contradição - O conhecimento da opinião singular tem diante de si o imediato dos interesses particulares, unidos pela universalidade dos partidos. O problema é a verdade da opinião, ou seja, o universal é uma unidade indiferente de multiplicidade de diferentes interesses particulares. Trata-se de um problema epistemológico, ou seja, como apreender a verdade da opinião, e ontológico, isto é, a realidade corresponde ao opinar da consciência? A verdade é que a realidade é, ao mesmo tempo, una e múltipla. A tensão da contradição dá-se entre a realidade do partido em sua identidade universal e as múltiplas diferenças de interesses particulares inerentes nele. $O$ movimento entre a unidade e a diferença é um jogo de forças de oposição dual entre o universal (unidade) e o particular (diferença). $O$ jogo de oposição entre as duas forças explicita o jogo do fenômeno da opinião pública: é a contradição nela mesma. Vejamos, agora, qual é a lógica imanente neste fenômeno. 


\subsection{Lógica da Opinião Pública}

O fenômeno da OP tem na internet e nas redes sociais a expressão imediata da luta por reconhecimento na sociedade global corporativa. A rede de opiniões aparece sob uma lógica da contradição que se desdobra em esferas de reflexão como (1) identidade/diferença e diversidade, (2) oposição e contradição.

a) Reflexividade da opinião diversa: Hegel descreve uma rede complexa de categorias para explicitar o movimento lógico da essência em sua reflexividade nos momentos da identidade/diferença/diversidade (HEGEL, 2016). O que nos interessa é considerar os aspectos desta reflexividade que podem ser relacionados a reflexividade da opinião pública como contradição.

A essência começa sua reflexividade como identidade igual a si mesma, ou seja, a igualdade consigo significa que ela é autossuficiente na sua autorrelacionalidade em movimento de identificação reflexiva. Porém, dentro desse movimento da reflexividade da identidade emerge a diferença, na medida em que a identidade se diferencia de si mesma pela reflexão. Assim, a identidade e a diferença são momentos do todo da essência em reflexão. Esses dois momentos comportam-se exteriores uns aos outros, assumindo uma lógica da reflexão exterior, isto é, ela relaciona esses momentos como igualdade externa e desigualdade externa em um mesmo substrato que é o objeto diverso. Assim, a reflexão exterior é um ato de comparar que relaciona o diverso com a igualdade e a desigualdade, isto é, a partir de um terceiro externo aos momentos do objeto. A diversidade é a diferença externa refletida dentro de si mesma, que resulta no subsistir indiferente do diverso no ser posto, como uma relação dos momentos da igualdade e desigualdade. Então, eles são, ao mesmo tempo, igual e desigual, "a igualdade e a desigualdade, são diversos dentro de um e do mesmo, ou seja, de que a diferença que se rompe é, ao mesmo tempo, uma e a mesma relação" (HEGEL, 2016, p. 69), aparecendo assim a reflexão de oposição.

b) Reflexividade da opinião em contradição: Hegel introduz os termos positivo e negativo para descrever a oposição lógica. Quando o positivo tem 
dentro de si o negativo e vice-versa, então temos uma relação de oposição imanente à essência. Essa reflexividade contrapõe o positivo e o negativo em um mesmo campo lógico, tensionando uma oposição crescente até em que os polos opostos se afirmam autossubsistentes. Aqui, ocorre uma exclusão e inclusão simultâneas entre os polos opostos, ou seja, o positivo exclui e inclui o negativo e vice-versa. Então, temos em um mesmo campo a contradição lógica e ontológica: "Todas as coisas são em si mesmas contraditórias" (HEGEL, 2017, p. 87). Pode-se descrever a contradição como uma relação vertical e horizontal, ou seja, a reflexão vertical exclui o campo oposto (autoexclusão da sua negação), depois, a reflexão horizontal inclui o campo negativo (autorrelacionalidade da sua negação), isso tem por resultado que essa determinação não tem subsistência, de modo que ela é dissolvida e impulsionada para além de si, isto é, ela está em movimento. Então, a reflexividade lógica supera sua contradição, porém, a reflexividade continua, permanentemente, em uma outra unidade dialética em contradição. A contradição constitui-se, desse modo, o fundamento do movimento lógico e ontológico (ver IBER, 2018). Pode-se representar o desenvolvimento da oposição e da contradição conforme Gráfico 1 (COSTA, 2018, p.10): 


\section{Gráfico 1 - Representação do desenvolvimento da oposição e da contradição}

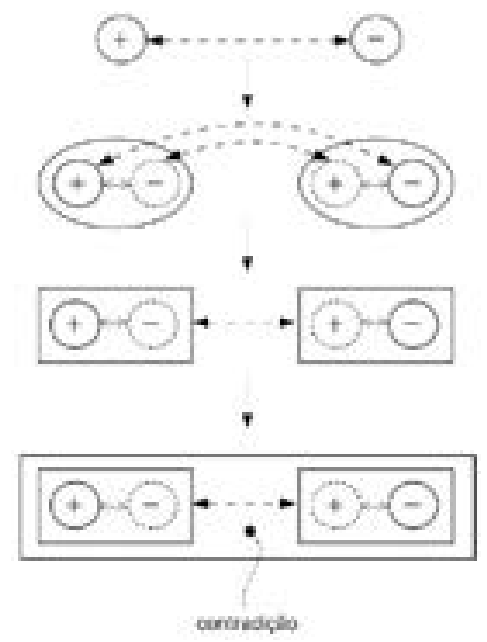

Fonte: Extraído de COSTA, 2018, p.10.

Após esta reconstrução da lógica da contradição pode-se relacioná-la com a lógica da contradição da OP através de dois momentos: primeiro, a reflexividade da diversidade explicita a opinião externa que compara um fato em termos de igualdade/desigualdade afirmando apenas identidades e diferenças que são iguais ou desiguais. Até que esta reflexividade torna essa diversidade oposta em seu interior. Então, temos o segundo momento, que é a oposição das opiniões como afirmações positivas e negativas dentro de um campo fático em que a reflexividade exclui e inclui, ao mesmo tempo, os polos opostos de opiniões. Então, a reflexividade imanente em cada um dos polos de opiniões "positivas-negativas" e "negativas-positivas" tornam-se autossubsitentes excluindo-se e incluindo-se, mutuamente, dissolvendo-se e criando uma anulação das contradições opostas e constituindo-se em um novo movimento do real. Essa lógica da opinião será explicitada na relação com a política da OP. 


\subsection{Política da Opinião Pública}

Constata-se em nível político a constituição de uma esfera de opinião pública internacional influenciada pelo fenômeno da globalização e mediada pelas redes sociais. Dois problemas são identificados neste cenário: as Fake News (FN) e a pós-verdade. As FN são o fenômeno que consiste em difundir intencionalmente notícias falsas através das mídias sociais, internet e através de jornal impresso, televisão e rádio. A intenção é enganar a opinião pública com o interesse de obter lucros financeiros ou políticos. O conteúdo falso é fabricado para aumentar o número de leitores ou influenciar a opinião para alcançar diferentes objetivos. Por exemplo, para obter receitas de publicidade através de anúncios online ou promover um candidato ou a polarização política. As FN são informações que não representam a realidade, mas a "pós-verdade". Esse neologismo foi criado para expressar o fenômeno relacionado às $\mathrm{FN}$, isto é, as falsas informações são consideradas verdades não pelo seu conteúdo, mas pela quantidade de pessoas que acessam tal notícia e acreditam que seja verdadeira. A verdade é uma relação entre o sujeito e o objeto em que os indivíduos inseridos em contextos particulares são habilitados a identificar uma universalidade objetiva que justifique suas opiniões. Porém, no caso das FN e a pós-verdade a relação entre o sujeito e os fatos objetivos não são mediados pelas estruturas lógicas e ontológicas universais, mas pela opinião singular desvinculada da relação com particularidades em contradição e a universalidade verdadeira.

O cenário das FN e da pós-verdade, segundo nosso entendimento, reforça a necessidade da defesa da liberdade da opinião pública e da liberdade de imprensa. Em que medida o conceito da contradição da opinião pública de G. W. F. Hegel contribui para compreender a nova esfera pública? A luta por liberdade de imprensa, descrita por J. S. Mill, no contexto do liberalismo do século XIX, pode ser útil na análise do problema das mídias, da democracia e da opinião pública no quadro das lutas democráticas do século XXI? 
A Modernidade instituiu a publicidade como um conceito para o avanço na proteção do direito à liberdade de imprensa e de opinião: “Todo ser humano tem direito à liberdade de opinião e expressão; este direito inclui a liberdade de, sem interferências, ter opiniões e de procurar, receber e transmitir informações e ideias por quaisquer meios, independentemente de fronteiras" (DIREITOS HUMANOS, art. 19) ${ }^{9}$. Esse conceito constituiu-se, simultaneamente, ao da formação da esfera pública. Há uma mútua imbricação entre publicidade e esfera pública, liberdade de imprensa e opinião pública ${ }^{10}$.

\section{a) Publicidade e contradição}

Em nível filosófico, Kant teoriza a publicidade como um estágio de maioridade, como uma emancipação da humanidade. É Hegel, no entanto, que tornará explícita a teoria da opinião pública ao tematizar a contradição como sendo seu movimento imanente. A opinião pública é um fenômeno da contradição das opiniões em todos os níveis da sociedade. O diagnóstico hegeliano sobre o fato da opinião pública embasa-se na constatação (I) da emergência da esfera pública, que se manifesta sobretudo na dimensão política através dos debates parlamentares. Aqui, os cidadãos podem expressar suas opiniões em um espaço de liberdade. (II) Essa liberdade amplia-se através das opiniões publicadas através das mídias, que no caso do contexto do século XIX dá-se, sobretudo, através dos jornais. (III) Há perspectivas diferentes de opiniões observadas por Hegel, por exemplo, a opinião política e a científica. Face ao pluralismo de opiniões, coloca-se o problema da responsabilidade moral e jurídica quanto ao direito da liberdade de imprensa. Em suma, eis o cenário, grosso modo, em que o filósofo faz o seu diagnóstico.

Esse diagnóstico, em nível filosófico, é analisado sob o ponto de vista lógico a partir da contradição como apresentamos acima. Há um movimento

\footnotetext{
9 United Nations Human Rights. Disponível em: http://www.ohchr.org/EN/Pages/WelcomePage. aspx. Acesso em: 12 abr. 2019.

10 Daqui em diante reproduzimos com algumas modificações e atualizações do texto já publicado em Projetos de Filosofia Il de Agemir Bavaresco, Caetano Sordi e Paulo R. Konzen. Mídias, Democracia e Opinião pública: Diagnósticos, Teorias e Análises, 2012, p. 30-38.
} 
entre forças de qualquer realidade que entram em oposição. As forças não se excluem na oposição, antes elas entram em um processo de interação ou relação mútua. Nesse movimento de oposição, crescem as possibilidades de oposições plurais, fazendo emergir um estado de contradição. Assim, alcança-se uma nova realidade de opiniões opostas, ou seja, gera-se um novo conceito, isto é, a efetividade da força da contradição. Essa força supera as oposições e mantém a tensão dialeticamente aberta para novas contradições, ou seja, para novos conceitos e novos cenários da realidade.

A partir da contradição, entende-se a opinião pública como um fenômeno em que as opiniões se opõem em um intenso e diversificado processo de interação. Isso é visto como algo muito importante para o processo político e científico, pois faz emergir a contradição, ou seja, um novo conceito do político e da ciência, que Hegel chama de efetividade. A opinião efetivada é aquela que passou de seu estágio imediato para a mediação das oposições pessoais, grupais, institucionais e alcançou uma ideia que une dialeticamente a realidade e o conceito. A esfera pública através das mídias permite a expressão da oposição das opiniões, sob as formas mais variadas, como os pré-juízos imediatos do senso comum, os sensos artísticos, as doutrinas religiosas, as hipóteses científicas, as teorias filosóficas etc. Nessa dialética de perspectivas das opiniões emerge um cenário plural e complexo de relações e tensões entre grupos de interesses, órgãos de poder privado e público, que se chama a contradição da opinião pública. Aqui, nascem novas efetividades, ou seja, novas ideias econômicas, sociais, políticas, científicas etc.; novos conceitos artísticos, religiosos e filosóficos.

A contradição hegeliana oferece-nos um diagnóstico e uma compreensão da opinião pública relevante para compreender tanto o seu tempo como o quadro complexo da sociedade contemporânea. Mas, como a opinião pública é tratada, posteriormente, por J. S. Mill? Qual é o seu diagnóstico e horizonte interpretativo para analisar a opinião pública? 
b) Utilidade e verdade

O horizonte utilitarista está presente na filosofia política de J. S. Mill e, por isso, em sua defesa irredutível da liberdade de expressão. Ele agrega os parâmetros utilitaristas (utilidade, escala de benefícios, consequencialismo e imparcialidade) uma vez que, na concepção deste filósofo, uma sociedade onde vigora a liberdade de expressão traz consequências mais positivas para seus membros do que aquelas em que a liberdade é cerceada; e o livre opinar é um regime mais adequado do que a censura frente à flagrante parcialidade das opiniões particulares.

Mill apresenta sua teoria da liberdade de expressão em seu livro Sobre a Liberdade (1991). A liberdade de expressão e opinião faculta aos sujeitos entrarem em contato com as mais diversas apreensões do objeto em disputa. É melhor que a liberdade de opinião e expressão seja mantida e salvaguardada porque, de acordo com Mill, ainda que cada indivíduo possa ter uma visão reduzida e particular do todo, e ainda que o "público" seja formado, em sua maior parte, pela opinião de indivíduos tolos, é como um dever que se impõe aos Estados e aos sujeitos procurar formar "as opiniões mais verdadeiras que puderem", o que só acontece quando as opiniões pessoais são confrontadas umas contra as outras. Isto é, Mill não pode ser acusado de relativismo, pois, o fato de que se deva assegurar às diversas versões da realidade o mesmo direito de serem expressas não implica afirmar que sejam todas verdadeiras. Ao contrário, quando usa termos como "indivíduos tolos" e "épocas menos ilustradas", Mill admite a existência da verdade ou de pelo menos algum critério de veracidade. O problema que se lhe impõe são as condições de acesso público à verdade, na medida em que ela apenas pode ser trazida à tona depois do embate de opiniões. Para Mill, esse embate traz consequências positivas à própria verdade.

Cercear qualquer tipo de opinião, independentemente do seu valor de veracidade, acaba sendo um desserviço à própria verdade, já que "se a opinião estiver correta, [os sujeitos] estão privados de trocar seu erro pela verdade; se estiver errada, eles perdem [...] a percepção vívida e clara que a verdade produz quando é contrastada com o erro" (MILL, 1991, p. 21). 
c) Publicidade, contradição e utilidade

Kant inaugura, como vimos, as discussões a respeito da opinião pública através da publicidade. A publicidade é um conceito político que cria na filosofia política a ideia de esfera pública como estrutura de garantia dos direitos individuais. $\mathrm{O}$ direito de expressar a própria opinião tem na publicidade sua legitimação.

Hegel introduz o conceito da contradição. Ele analisa o fato da opinião pública e a compreende como uma contradição, ou seja, o direito que o cidadão tem de dizer sua opinião livremente permite que se manifestem opiniões opostas. Essa é a lógica da opinião, dizer o que se pensa de forma imediata extravasando a contradição dos pré-juízos, das preferências, dos interesses etc., articulada pela mediação das instituições sociopolíticas.

Mill, por fim, destaca que também existe o conceito da utilidade, guiando a defesa e a manutenção da opinião pública livre, pois, como vimos, ela traz benefícios para as coletividades onde é aplicada. Uma sociedade democrática permite que os seus cidadãos satisfaçam seu desejo de formar as melhores opiniões possíveis e conforme o cenário mais adequado à consideração imparcial de todas as opiniões, sem privilégios arbitrários para uma em especial. Pode-se afirmar que Mill aplicou o conceito moral da utilidade à opinião pública. Há felicidade em dizer a própria opinião. Mais que isso, há um prazer em expressar o que se pensa. $O$ indivíduo busca um benefício ou um interesse em querer influenciar o outro com a sua opinião. É útil ao indivíduo garantir o prazer moral de ter sua opinião reconhecida pelo público. O jogo das opiniões reconhece a utilidade de todos dizerem a sua opinião. Porém, a justificação das várias opiniões dá-se pela imparcialidade, ou seja, a opinião precisa ser útil para o maior número de indivíduos e não apenas satisfazer a parcialidade de algumas opiniões.

Temos, assim, a publicidade, a contradição e a utilidade como três componentes da opinião pública. Pensamos que eles são muito consistentes para poder compreender o fato da opinião pública. A publicidade da política, a lógica da contradição e a moral utilitarista são conceitos 
constitutivos da opinião pública. Eles permitem entender os novos cenários da esfera pública construída ou influenciada pelas novas mídias e ampliada nacional e internacionalmente. Assim, a rede emaranhada das opiniões segue uma lógica da contradição, no embate utilitário dos interesses nacionais e internacionais, legitimando-se pela força da publicidade, ou seja, de esferas públicas em jogo democrático emancipatório.

Frente a esta tese do papel emancipatório da opinião pública, Iber (2018), compreende que ela continua a manter o mesmo papel legitimador de dominação política. A rede social é, em primeiro lugar, a nova pátria do indivíduo burguês, ou seja, é uma ilusão pensar que as redes sociais sejam por si mesmas uma alternativa emancipadora em relação à mídia estabelecida. Antes, elas são uma determinação progressiva da opinião pública tradicional: "vinho novo em odres velhos". Contra a tese de que a internet e as redes sociais seriam o meio da comunicação ilimitado dos cidadãos uns para com os outros; e que as informações e as divulgações sobre medidas políticas forçariam os governos a transparência total, empurrando-os para a democracia verdadeira, ele contra argumenta de que a dominação política não pode ser eliminada, apenas, através de informações. Publicidade sobre medidas políticas não substituem a necessidade da avaliação crítica da dominação política e do engajamento prático contra ela. Atrás de monitores não se faz revolução. Em segundo lugar, conclui lber, todo o canal de comunicação quer seja público ou privado ainda que eles sejam completamente autônomos - servem apenas para comunicar o que se quer e como se quer as próprias opiniões e interesses.

\section{Considerações finais}

As contradições da democracia representativa mostram, de um lado, a crescente "colonização" do mundo da vida, como afirma Habermas, através da dominação capitalista, impedindo a integração social e a participação ativa na esfera pública. Ou seja, o próprio modelo de democracia neoliberal é posto em questão. De outro lado, explicitamos as "ondas democráticas" e as 
teorias da democracia, segundo a Ciência Política, mostrando a contradição entre a concepção dos filósofos políticos que incluem a participação dos cidadãos e o processo de formação de opinião pública na análise de regimes políticos, em oposição a concepção de teóricos que defendem a apatia política e a participação limitada da representação política, consideradas positivas para a estabilidade do regime. Enfim, a explicitação da opinião pública compreendida como o fenômeno da contradição oferece-nos um potencial de análise da democracia como a subjetivação da permanente capacidade e os limites de opinar dos cidadãos.

\section{Referências}

ARISTÓTELES. Política. Edição bilíngue. Tradução António Campelo Amaral, Carlos de Carvalho Gomes. Lisboa: Vega, 1998.

ARTAZA, M. La ciencia política, la historia y las instituciones. Revista interdisciplinar de estúdios histórico-jurídicos, [S. I.], n. 18, p. 45-74, 2015. https:// doi.org/10.4067/s0716-54552004002600049

AUDARD, Catherine. Cidadania e democracia deliberativa. Tradução Walter Valdevino. Porto Alegre: Edipucrs, 2006.

AVRITZER, Leonardo; COSTA, Sergio. Teoria Crítica, Democracia e Esfera Pública: Concepções e Usos na América Latina. DADOS: Revista de Ciências Sociais, Rio de Janeiro, v. 47, n. 4, p. 703-728, 2004. https://doi.org/10.1590/ $\underline{\text { s0011-52582004000400003 }}$

BADIE, Bertrand e HERMET, Guy. Política comparada. México: Fondo de Cultura Económica, 1993.

BAVARESCO, Agemir; SORDI, Caetano; KONZEN, Paulo R. Mídias, Democracia e Opinião Pública: Diagnósticos, Teorias e Análises. In: BAVARESCO, Agemir; VILLANOVA, Marcelo Gross; RODRIGUES, Tiegüe Vieira. Projetos de filosofia II. Porto Alegre: EDIPUCRS, 2012. p. 8-39.

COHEN, Jean; Andrew Arato. Civil Society and Political Theory. Cambridge, MA: The MIT Press, 1992. https://doi.org/10.1177/089692059201900208

CONSTANT, Benjamin. A liberdade dos Antigos comparada à dos Modernos. Tradução Emerson Garcia. São Paulo: Atlas, 2015. 
COSTA, Antônio C. da Rocha. Apresentação. Porto Alegre: PPG Filosofia PUCRS, 2018. Apresentação em Seminário sobre "Doutrina da Essência: o problema do fundamento."

DAHL, Robert. A democracia e seus críticos. Tradução Patrícia Ribeiro. São Paulo: Martins Fontes, 2012. https://doi.org/10.26694/rcp.issn.2317-3254. v1i12012p151-163

DAHL, Robert. Um prefácio à democracia econômica. Tradução Ruy Jungmann. Rio de Janeiro: Jorge Zahar editor, 1990.

DAHL, Robert. A poliarquia. São Paulo: Ed. USP, 1997.

DUVERGER, Maurice. Introdução. In: DUVERGER, Maurice. Ciência Política: teoria e método. $2^{a}$. Edição. Rio de Janeiro: Zahar, 1976.

ESPOSITO, Roberto. Bios: Biopolítica e filosofia. Tradução M. Freitas da Costa. Lisboa: Edições 70, 2010.

FARR, James. The History of Political Science. American Journal of Political Science, [S. l.], v. 32, n. 4, p. 1175-1195, 1988.

FORST, Rainer. Contextos da justiça: Filosofia política para além de liberalismo e comunitarismo. Trad. Denilson Luís Werle. São Paulo: Boitempo, 2010.

GABOARDI, Ediovani A. O papel da contradição na experiência de determinação da verdade na certeza sensível e na percepção da Fenomenologia de Espírito de Hegel. Contradictio, Curitiba, v. 1, n. 1, [S. l.], p. 62-73, dez. 2008. https://doi.org/10.5380/contra.viio.12017

GUTMANN, Amy; Thompson Dennis. Why Deliberative Democracy?. Princeton, New Jersey: Princeton University Press, 2004. https://doi.org/10.1007/ \$11615-007-0039-0

HABERMAS, Jürgen. Direito de democracia: entre facticidade e validade, v. 2. Tradução Flávio Siebeneichler. Rio de Janeiro: Tempo Brasileiro, 1997.

HABERMAS, Jürgen. A Inclusão do Outro: estudos de teoria política. Tradução George Sperber e Paulo Soethe. São Paulo: Loyola, $2002 a$.

HABERMAS, Jürgen. Agir comunicativo e razão destranscendentalizada. Tradução. Lucia Aragão. Rio de Janeiro: Tempo Brasileiro, 2002b.

HABERMAS, Jürgen. Mudança estrutural da esfera pública: Investigações quanto a uma categoria da sociedade burguesa. Tradução Flávio Kothe. Rio de Janeiro: Tempo Brasileiro, 2003. https://doi.org/10.1590/s167939512010000400013 
HABERMAS, Jürgen. Teoria do agir comunicativo, 1: racionalização da ação e racionalização social. Tradução Paulo A. Soethe. Revisão de Flávio Beno Siebeneichler. São Paulo: Editora WMF Martins Fontes, 2012. https://doi. org/10.11606/t.27.2013.tde-19092013-102433

HABERMAS, Jürgen. Na esteira da tecnocracia: pequenos escritos políticos XII. Tradução Luiz Repa. São Paulo: Editora Unesp, 2014.

HEGEL, Georg Wilhelm Friedrich. Linhas fundamentais da filosofia do direito, ou direito natural e ciência do Estado em compêndio. Trad. Paulo Meneses [et al.]. São Leopoldo, RS: Ed. UNISINOS, 2010. https://doi.org/10.11606/ issn.2318-8235.v74iop 57-62

HEGEL, Georg Wilhelm Friedrich. A Doutrina da Essência. Tradução Christina G. Iber e Federico Orsini. Petrópolis: Vozes, 2017.

HOBBES, Thomas. Leviatã ou matéria, forma e poder de uma república eclesiástica e civil. Trad. João Paulo Monteiro, Maria Beatriz Nizza da Silva, Claudia Berliner. São Paulo: Martins Fontes, 2003.

HONNETH, Axel. O direito da liberdade. Tradução Saulo Krieger. São Paulo: Martins Fontes, 2015.

HUNTINGTON, Samuel. A Terceira Onda: Democratização no Final do Século XX. São Paulo: Editora Ática, 1994.

IBER, Christian. A proposição da contradição na Doutrina da Essência de Hegel. Porto Alegre: PPG filosofia, 2018. Material impresso usado em Seminário sobre "A contradição lógica da essência de Hegel. https://doi.org/10.15448/1984$\underline{6746.1996 .164 .35916}$

JAEGER, Werner Wilhelm. Paideia: a formação do homem grego. 3. ed. Tradução Artur Parreira. São Paulo: Martins Fontes, 1994.

KANT, Immanuel. Fundamentação da metafísica dos costumes. Tradução Paulo Quintela. São Paulo: Abril Cultural, 1974.

KANT, Immanuel. O conflito das faculdades. Tradução Artur Morão. Lisboa: Edições 70, 1993.

MACPHERSON, C. B; CANADIAN BROADCASTING CORPORATION. The Real World of Democracy. Nova York: Oxford University Press, 1966.

MARQUES, Teresa Cristina Schneider. Transições políticas na América Latina em perspectiva comparada. Pensamento plural (UFPEL), Pelotas, v. 06, p. 57-69, 2010. 
MARSHALL, Thomas. Cidadania, classe social e status. Rio de Janeiro: Zahar, 1967. MILL, John Stuart. Sobre a liberdade. Tradução e prefácio de Alberto da Rocha Barros; Apresentação de Celso Lafer. 2. ed. Petrópolis, RJ: Vozes, 1991.

MOUFFE, Chantal. The Democratic Paradox. New York: Verso, 2000.

NOZICK, Robert. Anarchy, State, and Utopia. Oxford UK \& Cambridge USA: Blackwell, 1974.

O'DONNELL, Guilhermo. Democracia, agência e Estado: teoria com intenção comparativa. São Paulo: Paz e Terra, 2011.

OFFE, Claus. “A Democracia Partidária Competitiva e o Welfare State Keynesiano: fatores de estabilidade e desorganização". In: Problemas Estruturais do Estado Capitalista. Rio de Janeiro: Tempo Brasileiro, 1984, p. 363-364.

ORSINI, Federico. A teoria hegeliana do silogismo: tradução e comentário. Porto Alegre: Editora Fi, 2016.

PATEMAN, Carole. Participação e teoria democrática. Rio de Janeiro: Paz e Terra, 1992.

PETRUCCIANI, Stefano. Modelos de filosofia política. Tradução José Vidigal. São Paulo: Paulus, 2014.

PETTIT, Philip. “Democracia e contestabilidade”. In: MERLE, Jean-Christophe; MOREIRA, Luiz. Direito e Legitimidade. São Paulo: Landy, 2003. p. 370-384. RANCIÈRE, Jacques. Ódio à democracia. Tradução Marina Echalar. São Paulo: Boitempo, 2014.

RAWLS, John. O liberalismo político. Tradução Álvaro de Vita. São Paulo: Martins Fontes, 2011.

SCHUMPETER, Joseph A. Capitalismo, socialismo e democracia. São Paulo: Editora da Unesp, 2017.

SANTOS, Boaventura de Souza; AVRITZER, Leonardo. Introdução: para ampliar o cânone democrático. In: SANTOS, Boaventura de Souza (org.). Democratizar a democracia: os caminhos da democracia participativa. 4. ed. Rio de Janeiro: Civilização brasileira, 2009.

SARTORI, Giovanni. The Theory of democracy revisited. New Jersey: Chatam House Publishers, 1987.

TATAGIBA, Luciana. Os protestos e a crise brasileira. Um inventário inicial das direitas em movimento (2011-2016). Revista Sinais Sociais, Rio de Janeiro, v. 11, p. 71-98, 2017. https://doi.org/10.7476/9788526815025.0004 
TILLY, Charles. Democracy. Cambridge: Cambridge Press, 2007.

TOCQUEVILLE, Alexis de. A democracia na América. Tradução Neil Ribeiro da Silva. 3. ed. São Paulo: Edusp, 1987. Vol 4.

WHITE, Stephen. Razão, justiça e modernidade: a obra recente de Jürgen Habermas. Tradução Márcio Pugliesi. São Paulo: Ícone, 1995.

\section{Endereço Postal}

\section{Agemir Bavaresco}

Escola de Humanidades da PUCRS

Avenida Ipiranga 6681 - Prédio $8-4^{\circ}$ Andar,

Partenon, Porto Alegre - RS, 90619-900 